\title{
KESADARAN HUKUM SEBAGAI ALAT PENGENDALI PELAKSANAAN HUKUM DI INDONESIA
}

Oleh :

\author{
Rahma Marsinah, SH., MM. \\ Dosen Tetap Fakultas Hukum Universitas Ibnu Chaldun - Jakarta \\ Kandidat Doktor Ilmu Hukum
}

\begin{abstract}
Abstrak :
Filsafat hukum mempunyai fungsi yang strategis dalam pembentukan masyarakat sadar hukum dan taat hukum di Indonesia. Hukum dalam patokan ilmu untuk manusia, atau sosial ilmu, karena merupakan bagian integral dan penting dalam komponen masyarakat dan budaya. Dengan demikian hukum merupakan salah satu bentuk budaya untuk kendali dan regulasi perilaku manusia, baik individual atau kolektif dalam penerapannya. Mengingat hukum merupakan alat utama untuk kontrol sosial pada masyarakat modern serta dalam masyarakat primitif, maka pembentukan masyarakat sadar hukum dan taat akan hukum merupakan cita-cita dari adanya norma-norma yang menginginkan masyarakat yang berkeadilan sehingga sendi-sendi dari budaya masyarakat akan berkembang menuju terciptanya suatu sistem masyarakat yang menghargai satu sama lainnya.
\end{abstract}

\section{A. PENDAHULUAN}

Hukum senantiasa harus dikaitkan dengan masyarakat dimanapun hukum itu bekerja. Bidang pengetahuan hukum pada umumnya memusatkan perhatian pada aturaaturan yang dianggap oleh pemerintah dan masyarakat sebagai aturan-aturan yang sah berlaku dan oleh sebab itu harus ditaati, dan pengetahuan sosiologi sebagai keseluruhan yang memusatkan perhatian pada tindakantindakan yang dalam kenyataan diwujudkan oleh anggota masyarakat dalam hubungan mereka satu sama lain. Maka untuk pengembangan hukum dan pengetahuan hukum dalam kehidupan masyarakat agar tidak terpisah satu sama lain harus memperhatikan hukum dan kenyataan

- kenyataan masyarakat. ${ }^{1}$

Ada studi dalam ilmu hukum yang kemudian dikenal dengan "Sosio Legal" adalah studi ilmu hukum yang dapat menjelaskan tentang bekerjanya hukum dalam hidup keseharian warga masyarakat. Mengingat banyak persoalan kemasyarakatan yang rumit dan tidak bisa dijawab secara tekstual. Maka dalam situasi ini dibutuhkan suatu pendekatan hukum yang bisa menjelaskan hubungan antara hukum dan masyarakat. ${ }^{2}$

1 Sudjono Dirdjosisworo; Sosiologi Hukum, Studi tentang Perubahan Hukum dan Sosial; Cv. Rajawali; Jakarta, 1983; hlm. Xi.

${ }^{2}$ Sulisttyowati Irianto; Kajian Sosio Legal dan Implikasi Metodologisnya; Pustaka Larasan; hlm. 1 
Amat penting bagi seseorang yang hendak mempelajari hubungan antara hukum dan kenyataan yang ada di masyarakat, yang diwujudkan oleh kehidupan sosial anggota masyarakat tertentu, untuk mengetahui dimana letak tempat aturan - aturan hukum didalam kerangka teori sosial tertentu, memperlihatkan bagaimana pencipta atau pengembang teori yang bersangkutan menanggapi hubungan antara aturan hukum, yang dalam hal ini juga dianggap merupakan kenyataan sosial, dengan kenyataan sosial lainnya, seperti agama, ilmu pengetahuan, ekonomi, politik peranata - pranata, kesatuan sosial. ${ }^{3}$

Kondisi hukum di Indonesia saat ini dirasa sangat memprihatinkan, hal ini ditandai dengan banyaknya masyarakat yang terluka oleh hukum. Selain itu ada kemarahan masyarakat pada mereka yang memanfaatkan hukum untuk mencapai tujuannya tanpa menggunakan hati nurani. Hal ini tentu mendapat sorotan yang amat tajam dari seluruh lapisan masyarakat. Oleh karenanya bidang hukum khususnya masalah penegakan hukum perlu segera melakukan reformasi yang meliputi semua proses dan sistem peradilan pidana.

Untuk mewujudkan prinsip-prinsip Negara hukum, diperlukan norma hukum atau peraturan perundangundangan, serta aparatur pengemban dan penegak hukum yang professional, berintegritas dan displin yang didukung oleh sarana dan prasarana hukum serta perilaku hukum masyarakat, sehingga hukum mempunyai posisi strategis dalam kehidupan berbangsa dan bernegara.

${ }^{3}$ Ibid.
Hukum sebagai suatu sistim dapat berperan dengan baik ditengah masyarakat. Dalam sistim peradilan pidana Indonesia mengalami campuran antara regulated Mandatory dengan Regulated Discretiory ${ }^{4}$.

Pada dasarnya Hukum berfungsi sebagai perlindungan kepentingan masyarakat, agar kepentingan masyarakat terlindungi. Untuk itu dalam pelaksanaan penegakan hukum ada tiga unsur yang selalu harus diperhatikan yaitu, kepastian hukum (Rechtssicherheit), kemafaatan (Zweckmassigkeit) dan keadilan (Gerechtigkeit). ${ }^{5} \quad$ Sedangkan permasalahan hukum di Indonesia dapat disebabkan oleh beberapa hal diantaranya yaitu sistem peradilannya, perangkat hukumnya, inkonsistensi penegakan hukum, intervensi kekuasaan, maupun perlindungan hukum.

Berkaitan dengan pandangan "hukum sebagai sistem" adalah pandangan yang cukup tua maskipun arti "sistem" dalam berbagai teori yang berpandangan demikian itu tidak selalu jelas dan tidak juga seragam. Kebanyakan ahli hukum berkeyakinan bahwa teori hukum yang mereka kemukakan di dalamnya terdapat suatu sistem. Tapi mereka jarang sekali menunjukkan tuntutan teori mana saja yang diperlukan untuk membangun kualitas sistematis hukum dan mana saja yang dapat memberikan deskriptif deteil atau memenuhi kebutuhan lainnya.

${ }^{4}$ Indhiyanto Seno Adji Seminar Nasional tgl 26 Juni 2014 yang diselenggarakan oleh Kejaksaan Agung. 1999: 145

5 Sudikno Mertokusumo; Penemuan Hukum, 
Asumsi umum mengenai sistem mengartikan bahwa secara langsung jenis sistem hukum tersebut telah ditegaskan lebih dari ketegasan yang dibutuhkan oleh sistem jenis manapun juga. Dalam beberapa hal tertentu beberapa ahli mencoba untuk memisahkan dan memperbaharui pandangannya antara lain adalah, pemikiran H.L A Hart:" "Meski tidak dapat dikatakan sebagai teori Positivistik yang sangat sistematis, namun pemikiran Hart tentang hukum sangat berpengaruh bagi perkembangan positivisme hukum modern. Bahwa inti pemikirannya terletak pada apa yang dijelaskan oleh Hart sebagai "Primery rules dan secondary rules". Untuk kedua ini harus ada dalam sistem hukum.

Dalam sejarah hukum didunia ini, hukum alam telah berulangkali digunakan sebagai dasar untuk memperkukuh sendi-sendi hukum suatu bangsa, setelah tatanan hukum yang lama dianggap tidak memadai lagi. Dalam menarik suatu tatanan hukum yang baru, mereka menggunakan kaidah-kaidah hukum alam yang bersifat rasional dan universal, misalnya salah satunya seperti dalam sistem hukum Anglo Saxon (yang dipraktekkan di Inggris dan USA), apa yang namanya hukum "equity" (pertama kali muncul di abad ke 15 Masehi) merupakan penjelmaan kaidah hukum alam kedalam hukum positif, ketika hukum positif terlalu kaku dan legalistis, dimana keadilan, banyak hanya bersifat deduksi rasional (rational deduction) dari

6 Otje Salman; Anthon F. Susanto; Teori Hukum; Mengingat, Mengumpulkan dan Membuka Kembali; Refika Aditama; hlm. 90. pikiran manusia saja sehingga mulai menjauh dari prinsip hukum alam. ${ }^{7}$

Teori hukum alam yang sekuler ini di zaman modern banyak dikembangkan oleh Huge Grotius, yang mendasari pendapatnya dari ajaran kaum Stoa dari zaman Yunani Klasik dan lepas sama sekali dari ajaran hukum alam Abad Pertengahan yang bersifat skolastik (berdasarkan agama), tetapi hanya bersandarkan atas rasio dan nurani manusia. Meskipun secara terminologi istilah hukum alam tetap tidak berubah dalam waktu ribuan tahun, tetapi substansi dan konotasinya mengalami perubahan dan perkembangan sesuai perkembangan pikiran manusia dan perkembangan zaman, seperti ketika pola pikir manusia bersifat kritis, apatis, pesimis, dan pragmatis di abad ke 21, maka kaidah hukum alam juga ditafsirkan secara kritis, apatis, pesimis, dan pragmatis, yang menyebabkan semakin lunturnya kepercayaan yang diberikan kepada hukum alam. ${ }^{8}$

Gejala lain dari abad ke 21 ditandai bangkitnya kembali agama, maka ada pula gejala bahwa penafsiran hukum alam yang dikaitkan kembali dengan kepercayaan terhadap Tuhan/ agama. Sebagaimana konsep tentang teori Moralitas Hukum, antara hukum dan moral ibarat dua sisi mata uang, dimana yang satu dapat menjustifikasi yang lain. Moral dapat menjadi basis bagi hukum untuk menetapkan dan menjalankan kaidah - kaidahnya, meskipun terdapat juga dibeberapa
${ }^{7}$ Munir Fuadi; Teori-teori Besar (Grand Theory) Dalam Hukum; Kencana Penada Media Group; Jakarta, hlm. 51

${ }^{8}$ Ibid. hlm. 62 . 
tempat kaidah-kaidah hukum yang tidak berkaitan atau kaitannya sangat kecil dengan moral. ${ }^{9}$

Dari sudut pandang filsafat hukum, bahwa filsafat hukum mempunyai fungsi yang strategis dalam pembentukan masyarakat sadar hukum dan taat di Indonesia. Hukum dalam patokan ilmu untuk manusia, atau sosial ilmu, karena merupakan bagian integral dan penting dalam komponen masyarakat dan budaya. Dengan demikian hukum merupakan salah satu bentuk budaya untuk kendali dan regulasi perilaku manusia, baik individual atau kolektif dalam penerapannya.

Mengingat hukum merupakan alat utama untuk kontrol sosial pada masyarakat modern serta dalam masyarakat primitif, maka pembentukan masyarakat sadar hukum dan taat akan hukum merupakan cita-cita dari adanya norma-norma yang menginginkan masyarakat yang berkeadilan sehingga sendi-sendi dari budaya masyarakat akan berkembang menuju terciptanya suatu sistem masyarakat yang menghargai satu sama lainnya. Untuk itu hukum dapat dipahami berdasarkan pendapat orang masingmasing antara lain: "Hukum adalah keseluruhan peraturan-peraturan atau kaedah-kaedah dalam suatu kehidupan bersama, keseluruhan peraturan tentang tingkah laku yang berlaku dalam suatu kehidupan bersama, yang dapat dipaksakan pelaksanaannya dengan suatu sanksi". ${ }^{10}$

\footnotetext{
${ }^{9}$ Ibid. hlm. 70
}

${ }^{10}$ Ibid. 40
Jadi, kebijakan penegakan hukum adalah usaha-usaha yang diambil oleh pemerintah atau suatu otoritas untuk menjamin tercapainya rasa keadilan dan ketertiban dalam masyarakat dengan menggunakan beberapa perangkat atau alat kekuasaan negara baik dalam bentuk undang-undang, sampai pada para penegak hukum antara lain polisi, hakim, jaksa, serta pengacara.

Dalam proses penegakan hukum terdapat empat elemen penting yang harus terlibat, yaitu hukum atau aturan itu sendiri, mental aparat hukum, fasilitas pelaksanaan hukum, kesadaran dan kepatuhan perilaku masyarakat. Persoalan yang muncul kemudian, ada pada penegak hukum yaitu perilaku aparat hukum, yang sampai saat ini ada dikenal adanya "Mafia Peradilan", merupakan cerminan dari proses penegakan hukum masa lalu, yaitu proses penegakan hukum di Indonesia dalam hubunganya dengan politik pada era reformasi. Mengingat pada masa lalu rezim orde baru ada menunjukan sistem politik yang tidak demokratis. Hal ini tentu berimplikasi pada proses penegakkan hukum yang buruk, seperti terjadinya mafia peradilan.

Bukan lagi merupakan rahasia bahwa praktek mafia peradilan yang melibatkan aparat penegak hukum seolah menunjukan kondisi yang tersistematis, mengingat hampir semua lini instansi penegak hukum (Kepolisisan, Kejaksaan, Pengadilan sampai Mahkamah Agung dan advokat) ada terlibat dalam jaringan Mafia Peradilan. Praktek korupsi yang melibatkan pejabat Negara terkadang diolah sedemikian rupa sehingga sulit 
disentuh hukum. Oleh karenanya mereka para pelaku dapat bebas menikmati uang hasil korupsinya. Dengan demikian orang bisa berpandapat bahwa penegakkan Hukum di Indonesia ibarat "pisau" tajam ke atas dan tumpul ke bawah. Hukum akan tegak kalau mengahadapi masyarakat kecil dan akan lentur ketika mengahadapi pemegang kekuasaan.

Bangsa yang beradab adalah bangsa yang menjalankan fungsi hukumnya secara merdeka dan bermartabat. Merdeka dan bermartabat berarti dalam penegakan hukum wajib berpihak pada keadilan, yaitu keadilan untuk semua. Sebab apabila penegakan hukum dapat mengaplikasikan nilai keadilan, tentulah penerapan fungsi hukum tersebut dilakukan dengan cara-cara berpikir yang filosofis.

Kepastian hukum merupakan perlindungan terhadap tindakan sewenang-wenang, yang berarti bahwa seseorang akan dapat memperoleh sesuatu yang diharapkan dalam keadaan tertentu. Sebaliknya masyarakat mengharapkan manfaat dalam pelaksanaan atau penegakkan hukum. Hukum adalah untuk manusia, maka pelaksanaan hukum atau penegakan hukum harus memberi manfaat bagi masyarakat. Selain itu masyarakat sangat berkepentingan bahwa dalam pelaksanaaan atau penegakan hukum, keadilan harus diperhatikan. Maka dalam pelaksanaan atau penegakan hukum harus adil. ${ }^{11}$
Dalam pasal 27 UUD 1945 dengan jelas tercantum: "Segala warga negara bersamaan kedudukannya di dalam hukum dan pemerintahan dan wajib menjunjung hukum dan pemerintahan itu dengan tidak ada kecualinya." Rumusan tersebut mengandung makna bahwa semua warga negara Republik Indonesia memiliki persamaan hukum dan hak-hak yang sama di hadapan pemerintah. Dengan demikian dalam Negara Kesatuan Republik Indonesia tidak boleh ada yang dinamakan diskriminasi terhadap warga negara.

Membuat masyarakat sadar hukum dan taat hukum saat ini bukanlah sesuatu yang mudah mengingat begitu banyak yang harus diupayakan oleh pendiri atau pemikir negeri ini untuk memikirkan hal tersebut. Dengan landasan pemikiran ini, penulis akan mencoba memaparkan mengenai kebijakan, problematika, dampak dan pemecahan penegakan hukum di Indonesia, ketidakpuasan masyarakat terhadap penegakan hukum dengan mengemukakan rumusan masalah:" Mengapa masyarakat pada kondisi saat ini cenderung tidak bisa patuh dan taat pada aturan hukum yang ada".

\section{B. PERMASALAHAN}

Berdasarkan uraian di atas maka untuk artikel ini penulis ada mengemukakan permasalahan yaitu, "Bagaimana Sistim Hukum dapat menjadi alat kontrol kesadarn hukum masyarakat untuk mencapai keadilan di Indonesia".

${ }^{11}$ Ibid. 146 


\section{KAJIAN TEORI DAN PEJELASAN UMUM}

Gambaran sekelumit latar belakang masalah yang diuraikan diatas hanya memperlihatkan bagaimana sesungguhnya masalah penegakan hukum, terutama penegakan hukum dibidang hukum pidana telah mengalami situasi yang tidak baik, karena dengan konsep "Negara Hukum" atau Rule of Law sesunggguhnya ini sudah di jadikan sebagai alat pembenar bahwa hukum memainkan peranannya yang penting dan berada diatas kekuasaan Negara dan politik, karena Indonesia menganut konsep Negara Hukum. ${ }^{12}$

Bahwa konsep Negara hukum ini dimaksudkan untuk membatasi kekuasaan penguasa Negara agar tidak menyalahgunakan kekuasaannya untuk menindas rakyat (abuse of power). Dengan demikian dapat dikatakan bahwa dalam satu Negara hukum, semua orang harus tunduk pada hukum yang adil, dan tidak seorang penguasapun yang kebal akan hukum. ${ }^{13}$ Ini merupakan suatu Negara berdasarkan Rule Of Law yang harus dijalankan secara paksa demi ketertiban, dan oleh karenanya kondisi itu mungkin saja akan berbenturan dengan hak dasar manusia. Maka kondisi ini akhirnya menyadarkan masyarakat bahwa keadilan tidak mungkin dicapai tanpa ketertiban, sedangkan ketertiban akan menjadi kesewenang-wenangan jika dilaksanakan tanpa terpenuhinya unsur keadilan, padahal kedua unsur ini merupakan dambaan masyarakat

${ }^{12}$ Munir Fuady; Teori Negara Hukum Modern (Rechtstaat); Refika Aditama; bandung, 2009; hlm. 2.

${ }^{13} \mathrm{Ibid}$. didalam Negara hukum dengan system Rule of Law.

Pada dasarnya pada penerapan konsep Rule Of Law bisa saja diterapkan menjadi "Rule Of Men" yang kondisinya membawa efek tidak baik bagi masyarakat karena pada pelaksanaan konsep tersebut tidak kelihatan, tersamar, tidak langsung, tidak personal, bahkan bisa jadi tertutup rapat oleh kaidah, argumen, dan logika hukum yang tumpangtindih, sebagaimana pada masa Orde Lama dan masa Orde baru yang mengkalim bahwa pada masa ini disebut memberlakukan konsep Negara hukum berdasarkan Pancasila. Namun yang terjadi dalam masyarakat adalah telah terjadi penyimpangan - penyimpangan terhadap teori Negara hukum, Seperti halnya dalam proses peradilan yang disangka adil bagi masyarakat ternyata dirasa tidak adil karena hukum tajam kebawah namun menjadi tumpul bila itu menyangkut masyarakat kalangan atas. ${ }^{14}$

Memahami Politik Hukum pada dasarnya harus melihat antara Politik dan Hukum yang merupakan dua topik ilmu dengan ranah yang berbeda. Hukum pada dasarnya dapat dipelajari dari berbagai sudut pandang. Maka lahirnya berbagai disiplin hukum seperti Filsafat Hukum, Ilmu Hukum, Teori Hukum, Sejarah Hukum, Sosiologi Hukum, Perbandingan Hukum, Logika Hukum, Psikologi hukum, dan selanjutnya ada Politik Hukum (Rechtspolitiek), adalah suatu bidang ilmu yang mempunyai ciri-ciri

\footnotetext{
${ }^{14}$ Ibid; hlm. 21.
} 
tertentu, yaitu kegiatan untuk menentukan atau memilih hukum mana yang sesuai untuk mencapai tujuan-tujuan yang dikehendaki oleh masyarakat. ${ }^{15}$

Antara kedua topik yang berbeda itu ternyata mempunyai sifat yang saling mempengaruhi. Pada tataran realitas kedua topik tersebut kadang-kadang menunjukkan bahwa hukum dapat mempengaruhi politik atau sebaliknya politik dapat mempengaruhi hukum. Moh. Mahfud MD mengemukakan tentang hal tersebut bahwa terdapat tiga macam jawaban untuk melihat hubungan antara hukum dan politik.

1. Pertama, hukum merupakan determinan politik, kegiatan politik harus tunduk pada hukum,

2. Kedua, pandangan yang melihat bahwa politik determinan atas hukum karena sesungguhnya hukum adalah produk politik yang sarat dengan kepentingan dan konfigurasi politik, dan

3. ketiga pandangan yang melihat bahwa hukum dan politik merupakan dua elemen subsistem kemasyarakatan yang seimbang, karena walaupun hukum merupakan produk politik maka ketika ada hukum yang mengatur aktivitas politik maka politikpun harus tunduk pada hukum. ${ }^{16}$

Ketiga macam jawaban di atas adalah bangunan teori yang dibangun berdasarkan realitas relasi antara dua sistem tersebut. Pada kesimpulan

${ }^{15}$ Satjipto Rahardjo, Ilmu Hukum; Alumni, Bandung; 1991, hlm 325; Melalui buku Imam Syaukani; A. Ahsin Thohari; Dasar-Dasar Politik Hukum, PT Raja Grafindo Persada, Jakarta; hlm.2.

${ }^{16}$ Imam Syaukani; A. Ahsin Thohari; DasarDasar Politik Hukum, PT Raji Grafindo Persada, Jakarta; hlm.5 - 8 akhir tulisannya Mahfud MD menyimpulkan bahwa sesungguhnya politik determinan atas hukum, hukum yang lahir merupakan cerminan konfigurasi politik. Dalam hubungan tarik menarik antara hukum dan politik maka sesungguhnya politik mempunyai energi yang cukup kuat untuk mempengaruhi hukum. Asumsi dasar tadi memperlihatkan bahwa dalam konfigurasi politik yang demokratis maka yang lahir adalah produk hukum yang responsif/populistik, sedangkan konfigurasi politik yang otoriter melahirkan produk hukum yang konservatif /ortodoks dan elitis. $^{17}$

Ada beberapa ahli hukum mendefinisikan Politik Hukum seperti Padmo Wahyono, Teuku Mohammad Radhie, Soedarto, Satjipto Rahardjo, Sunaryati Hartono, dan Abdul Hakim Garuda Nusantara. Dalam hal ini saya tertarik dengan pendapat dari Satjipto Rahardjo yang mendefinisikan Politik Hukum sesuai dengan keahliannya dibidang Sosiologi, dengan begitu penyataannya menjelaskan bahwa politik hukum digunakan untuk mencapai suatu tujuan sosial dan hukum tertentu dalam masyarakat. ${ }^{18}$

Berkaitan dengan Politik Hukum Nasional, tinjauan awalnya adalah memahami pengertian politik hukum yang diartikan sebagai, "Kebijakan dasar penyelenggara negara dalam bidang hukum yang akan, sedang dan telah berlaku, yang bersumber dari nilai-nilai yang berlaku di masyarakat untuk mencapai tujuan negara yang

\footnotetext{
${ }^{17}$ Ibid.hlm. 7 - 8

${ }^{18}$ Ibid. hlm. 29
} 
dicita - citakan". Jadi Politik Hukum Nasional adalah, Kebijakan dasar penyelenggara negara dalam bidang hukum yang akan, sedang dan telah berlaku, yang bersumber dari nilainilai yang berlaku di masyarakat untuk mencapai tujuan (Republik Indonesia) negara yang dicitacitakan. ${ }^{19}$

Hukum pada dasarnya bukan satusatunya yang berfungsi untuk menjadikan masyarakat sadar hukum dan taat hukum. Indonesia sebagai negara yang heterogen dalam membentuk formulasi hukum positif tentu penting kiranya sebelum membentuk suatu hukum yang akan mengatur perjalanan masyarakat, seharusnya mempertimbangkan filsafat hukum secara lebih komprehensif yang akan mewujudkan keadilan yang nyata bagi seluruh golongan, suku, ras, agama yang ada di Indonesia.

Peranan hukum didalam masyarakat sebagaimana tujuan hukum itu sendiri adalah menjamin kepastian dan keadilan. Hal ini dalam kehidupan masyarakat senantiasa terdapat perbedaan antara pola-pola perilaku atau tata-kelakuan yang berlaku dalam masyarakat dengan pola-pola perilaku yang dikehendaki oleh norma-norma (kaidah) hukum yang sudah ada seperti hukum adat.

Kondisi ini mungkin saja dapat menyebabkan timbulnya suatu masalah berupa kesenjangan sosial sehingga pada waktu tertentu cenderung terjadi konflik dan ketegangan-ketegangan sosial yang tentunya dapat mengganggu jalannya perubahan masyarakat sebagaimana arah yang dikehendaki.

Purnadi Purbacaraka dan Soerjono Soekanto menyebutkan sembilan arti hukum, yaitu: ${ }^{20}$

1. Ilmu pengetahuan, yaitu pengetahuan yang tersusun secara sistematis atas dasar kekuatan pemikiran;

2. Disiplin, yaitu suatu sistem ajaran tentang kenyataan atau gejalagejala yang dihadapi;

3. Norma, yaitu pedoman atau patokan sikap tindak atau perilaku yang pantas atau diharapkan;

4. Tata Hukum, yaitu struktur dan proses perangkat norma-norma hukum yang berlaku pada suatu waktu dan tempat tertentu serta berbentuk tertulis.

5. Petugas, yakni pribadi-pribadi yang merupakan kalangan yang berhubungan erat dengan penegakan hukum (law enforcement officer)

6. Keputusan Penguasa, yakni hasil proses diskresi;

7. Proses Pemerintahan, yaitu proses hubungan timbal balik antara unsur-unsur pokok dari sistem kenegaraan;

8. Sikap tindak ajeg atau perilaku yang teratur, yakni perilaku yang diulang-ulang dengan cara yang sama, yang bertujuan mencapai kedamaian;

9. Jalinan nilai-nilai, yaitu jalinan dari konsepsi-konsepsi abstrak

20 Rasjidi, Lili, Filsafat Hukum: Apakah itu hukum, cetakan kelima, Bandung, Remaja Rosdakarya, 1991, hal 1.

${ }^{19}$ Ibid. hlm. 58 
tentang apa yang dianggap baik dan buruk.

\section{PEMBAHASAN}

Berkaitan dengan "kesadaran hukum" diartikan secara terpisah dalam bahasa yang kata dasarnya "sadar" tahu dan mengerti, dan secara keseluruhan merupakan mengetahui dan mengerti tentang hukum. Menurut Ewick dan Silbey: "Kesadaran Hukum" mengacu ke cara-cara dimana orang-orang memahami hukum dan intitusiinstitusi hukum, yaitu pemahamanpemahaman yang memberikan makna kepada pengalaman dan tindakan orang-orang. ${ }^{21}$

Bagi Ewick dan Silbey, "kesadaran hukum" terbentuk dalam tindakan dan karenanya merupakan persoalan praktik untuk dikaji secara empiris. Dengan kata lain, kesadaran hukum adalah persoalan "hukum sebagai perilaku", dan bukan "hukum sebagai aturan norma atau asas" 22

Pentingnya kesadaran membangun masyarakat yang sadar akan hukum inilah yang diharapkan akan menunjang dan menjadikan masyarakat menjunjung tinggi institusi atau aturan sebagai pemenuhan kebutuhan untuk mendambakan ketaatan serta ketertiban hukum. Beberapa faktor yang mempengarui masyarakat tidak sadar akan pentingnya hukum adalah: "Adanya ketidak pastian hukum dan peraturan-peraturan bersifat statis dan

${ }^{21}$ Ali Achmad, Menguak Teori Hukum (Legal Theory) dan Teori Peradilan (Judicial Prudence) Termasuk Interprestasi Undang-undang (legisprudence,Kencana,2009, hlm 510.

${ }^{22}$ Ibid. hlm. 511 tidak efisiennya cara-cara masyarakat untuk mempertahankan peraturan yang berlaku". ${ }^{23}$

Berkaitan dengan "ketaatan hukum", hal ini tidak lepas dari kesadaran hukum, dan kesadaran hukum yang baik adalah ketaatan hukum, dan ketidak sadaran hukum yang baik adalah ketidak taatan. Pernyataan ketaatan atau kepatuhan hukum harus disandingkan sebagai sebab dan akibat dari kesadaran dan ketaatan hukum. Sebagai hubungan yang tidak dapat dipisahkan antara kesadaran hukum dan ketaataan hukum maka beberapa literaur yang di ungkap oleh beberapa pakar mengenai ketaatan hukum bersumber pada kesadaran hukum. Hal tersebut tercermin dua macam kesadaran, yaitu: ${ }^{24}$

1. Legal consciouness as within the law, kesadaran hukum sebagai ketaatan hukum, berada dalam hukum, sesuai dengan aturan hukum yang disadari atau dipahami;

2. Legal consciouness as against the law, kesadaran hukum dalam wujud menentang hukum atau melanggar hukum.

Ketaatan hukum merupakan kewajiban yang harus dilaksanakan dan apabila tidak dilaksanakan akan timbul sanksi. Tidaklah demikian dengan ketaatan sosial, ketaatan sosial manakala tidak dilaksanakan atau dilakukan maka sanksi-sanksi sosial yang berlaku pada masyarakat inilah

23 Rahardjo Satjipto, Ilmu Hukum, Citra aditya Bakti, Bandung, 1991, Edisi Revisi Hal.112

${ }^{24}$ Ali Achmad, Menguak Teori Hukum (Legal Theory) dan Teori Peradilan (Judicial Prudence) Termasuk Interprestasi Undang-undang (legisprudence),Kencana,2009, hlm 510. 
yang menjadi penghakim. Tidaklah berlebihan bila ketaatan didalam hukum cenderung dipaksakan.

Menjawab pertanyaan mengapa orang mentaati hukum, hal ini dapat di pahami karena hukum secara esensial bersifat relegius atau alami dan karena itu, tak disangkal akan membangkitkan keadilan..$^{25}$ Kewajiban moral masyarakat untuk mentaati hukum, meskipun memaksa namun dalam penerapan atau prakteknya kewajiban tersebut merupakan tidak absolut mengingat kemajemukan budaya yang tumbuh didalam masyarakat, norma-norma hidup dan tumbuh berkembang dengan pesat.

\section{E. KESIMPULAN}

Kesadaran hukum dan ketaatan atau kepatuhan hukum sering didengar ketika orang menyampaikan "Kesadaran hukum", dengan "Ketaatan Hukum" atau "Kepatuhan Hukum", sebagai suatu persepsi keliru. Pada dasarnya pemahaman Kesadaran hukum dan ketaatan hukum dapat dijelaskan bahwa:

1. Kesadaran hukum yang baik, yaitu ketaatan hukum, dan

2. Kesadaran hukum yang buruk, yaitu ketidaktaatan atau ketidak patuhan hukum.

Kewajiban moral masyarakat secara individu untuk mentaati hukum, tidak ada yang mengatakan bahwa kewajiban merupakan sesuatu yang absolut, sehingga terkadang secara moral, orang dapat melanggar hukum,

${ }^{25}$ Ibid. hlm. 352 namun tidak ada pakar hukum, yang secara terbuka atau terang-terangan menyatakan telah melanggar hukum, karena orang memiliki alasan moral yang kuat untuk melakukan apa yang diperintahkan oleh hukum, seperti, tidak melakukan penghinaan, penipuan, atau mencuri dari orang lain.

Pada dasarnya orang harus mentaati hukum, jika telah ada aturan hukum yang disertai dengan ancaman hukuman. Mereka yang yakin akan hukum, harus melakukan dengan bantuan pemerintah, dan mereka yakin, akan mendapat dukungan dari warga masyarakat.

\section{DAFTAR PUSTAKA}

Ali Achmad, Menguak Teori Hukum (Legal Theory) dan Teori Peradilan (Judicial Prudence) Termasuk Interprestasi Undang - undang (legisprudence, Kencana, 2009, hlm 510.

Indhiyanto Seno Adji Seminar Nasional tg1 26 Juni 2014 yang diselenggarakan oleh Kejaksaan Agung.

Imam Syaukani; A. Ahsin Thohari; DasarDasar Politik Hukum, PT Raji Grafindo Persada, Jakarta; hlm.5- 8

Munir Fuadi; Teori-teori Besar (Grand Theory) Dalam Hukum; Kencana Penada Media Group; Jakarta, hlm. 51-------; Teori Negara Hukum Modern (Rechtstaat); Refika Aditama; bandung, 2009; hlm. 2.

Otje Salman; Anthon F. Susanto;Teori Hukum; Mengingat, Mengumpulkan dan Membuka Kembali; Refika Aditama; hlm. 90. 
Rasjidi, Lili, Filsafat Hukum: Apakah itu hukum, cetakan kelima, Bandung, Remaja Rosdakarya, 1991, hal 1.

Rahardjo Satjipto, Ilmu Hukum, Citra aditya Bakti, Bandung, 1991, Edisi Revisi Hal.112

Satjipto Rahardjo, Ilmu Hukum; Alumni, Bandung; 1991, hlm 325; Melalui buku Imam Syaukani; A. Ahsin Thohari; Dasar-Dasar Politik Hukum, PT Raja Grafindo Persada, Jakarta; hlm.2.

Sudikno Mertokusumo; Penemuan Hukum, 1999: 145.

Sudjono Dirdjosisworo; Sosiologi Hukum, Studi tentang Perubahan Hukum dan Sosial; Cv. Rajawali; Jakarta, 1983; hlm. Xi.

Sulisttyowati Irianto; Kajian Sosio Legal dan Implikasi Metodologisnya; Pustaka Larasan; hlm. 1 